Article

\title{
Assessing Airbnb Logistics in Cities: Geographic Information System and Convenience Theory
}

\author{
Zhihua Zhang ${ }^{1}$ and Rachel J.C. Chen ${ }^{2, *}$ \\ 1 Department of Civil and Environmental Engineering, the University of Tennessee, \\ Knoxville, TN 37996-2313, USA; zzhang78@vols.utk.edu \\ 2 Department of Retail, Hospitality, and Tourism Management, the University of Tennessee, 246 Jessie Harris \\ Building, Knoxville, TN 37996-1911, USA \\ * Correspondence: rchen@utk.edu; Tel.: +1-865-974-0505
}

Received: 19 March 2019; Accepted: 19 April 2019; Published: 26 April 2019

check for updates

\begin{abstract}
City managers and planners seek insights into Airbnb logistics in cities for the purposes of effective lodging management. This requires managers and planners to gain a holistic understanding of Airbnb geographic dynamics, which has drawn limited attention in the literature. To fill this gap, this paper explored Airbnb supply and logistics in three cities (New York City, Los Angeles, and Chicago) through the lenses of geographic clustering and location convenience. We explored the spatial allocations of Airbnb supply in cities and investigated Airbnb's influencing factors at the census tract level, utilizing spatial regression models. The results showed that (1) the spatial distribution of Airbnb supply in all three cities has a clear center-peripheral pattern, indicating that Airbnb allocations predominate in the central area of the city; (2) the number of housing units and points of interest (POI) have an influential impact on Airbnb supply for three cities; (3) the proportion of youth population and employment has a positive effect on Airbnb supply in NYC and Chicago, but not in LA, while the distance to the city center negatively affects Airbnb supply in LA and Chicago, but not in NYC; (4) the income has a mixed effect on Airbnb supply in three cities, while the proportion of African Americans and education level has only a positive effect on Airbnb supply in NYC; and (5) rent is not associated with Airbnb supply for all three cities, which indicates that the Airbnb explosion may not contribute to rent increases in cities.
\end{abstract}

Keywords: Airbnb logistics; geographic information system; convenience theory

\section{Introduction}

In recent years, the sharing economy has undergone exponential growth among various business sectors such as transportation (e.g., Uber, Lyft) and accommodation (e.g., Airbnb). Uber had reached 5 billion rides around the world as of May 20, 2017 [1]. As of May 2018, Airbnb had served more than 300 million guests around the world [2]. The growing popularity of the sharing economy has contributed to increased convenience and lower prices for consumers. In the tourism and hospitality industry, Airbnb is a notable example of peer-to-peer (P2P) accommodations, allowing hosts to rent out their unused spaces to travelers. Airbnb creates a virtual community [3] that benefits both hosts and travelers; hosts can make extra money via hosting Airbnb, and travelers can gain a unique accommodation experience at less cost than that of a hotel room. While customers have benefited from the experiences of using Airbnb, there are challenges that have impacted the popularity of Airbnb, such as city and state law violations, safety issues, crime rates, and housing affordability. Airbnb is considered a sustainable way of delivering lodging services because it enhances the efficiency of resource-sharing processes. Additionally, the P2P accommodation system focuses on environmental-friendly efforts (e.g., less commercial laundary services) compared to certain mainstream hotel sectors [4]. On the other 
hand, due to its competitive low price, Airbnb can entice more overnight stays that would intensify various environmental pressures [5]. Thus, it is vital to examine the trends of Airbnb growth in order to project a sustainable development plan.

City managers and planners have been seeking insights into Airbnb logistics in cities for the sake of effective lodging management. This requires managers and planners to gain a holistic understanding of Airbnb geographic dynamics, which has received limited treatment in the literature. The importance of geography plays a key role in Airbnb's growth and expansion. For example, when choosing a unit posted on the Airbnb list, customers evaluate the location of the listing closely, and the price is partly defined by the geographic context of the Airbnb listing, indicating Airbnb is preferably concentrated in areas with geographic convenience. Additionally, residential clustering is a notable phenomenon in geography, which refers to the tendency of people with similar characteristics (e.g., race, ethnicity, and socioeconomic status) to live in the same neighborhood. It may shape the spatial distribution of Airbnb because, unlike a hotel, Airbnb listings can be easily established wherever houses and apartment buildings already exist.

This paper explored the Airbnb spatial patterns through the lens of residential clustering and geographic convenience. We first examined the concept and theory of residential clustering and geographic convenience, which are key factors affecting Airbnb spatial allocations. Then, we explored the relationships between residential clustering and geographic convenience and Airbnb spatial patterns across three cities in the USA (New York City, Los Angeles, and Chicago).

\section{Literature Review}

\subsection{Residential Clustering}

Residential clustering is a common feature of the urban landscape and a key factor in human geography that describes the phenomenon whereby people with similar characteristics such as race, ethnicity, and socioeconomic status tend to reside close to each other [6]. Recently, more studies have been devoted to discovering residential clustering patterns and exploring the factors contributing to these patterns [7-11]. Using the poverty data from the 2005-2009 American Community Survey, Lichter, Parisi, and Taquino [11] found that nearly 30\% of Americans live in poverty, and documented low-income families are more likely to be African Americans.

Residential clustering as an urban landscape feature can explain certain geographical phenomena. According to Thebault-Spieker et al. [12], the Uber waiting time is longer in lower social and economic status neighborhoods, demonstrating spatial disparity in Uber services. Similarly, for P2P accommodations, like Airbnb, there are limited yet increasing studies attempting to identify the socioeconomic characteristics affecting Airbnb location patterns [13,14]. Dudás, Vida, Kovalcsik, and Boros [13] performed a socioeconomic analysis of Airbnb in New York City and found that Airbnb tends to concentrate in those parts with a high proportion of youth, a significant number of housing units, and a large number of points of interest (POI). However, these studies mainly applied conventional regression models, which may ignore the spatial correlations of Airbnb supply-and-demand. Therefore, it is necessary to explore the underlying mechanisms of Airbnb location patterns with spatial regression models.

\subsection{Geographic Convenience}

Convenience is a notable concept evaluated by consumers before purchasing products and services, making it of great value in examining consumer purchasing behavior [15]. Convenience refers to the perceived time and effort required to purchase or use a service $[15,16]$ and has been widely explored and studied in service, retail, and marketing literature. There is an acknowledgment of the significant influence of convenience on critical marketing factors such as customer experience, customer satisfaction, customer loyalty, and repurchase intention [17-20]. 
Convenience is explored as a multidimensional construct. For example, Berry, Seiders and Grewal [15] proposed a multidimensional model of convenience and specified five classes of convenience: Decision convenience, access convenience, transaction convenience, benefit convenience, and post-benefit convenience. Jin and Kim [21] identified three important dimensions of convenience in discount store shopping: Facility convenience, service convenience, and shopping convenience. According to Anselmsson [22], convenience is related to opening hours, parking, ease of movement, and ability to find one's location in the mall. In addition to the abovementioned convenience types, geographic convenience, which is related to location or accessibility, is also a documented aspect of the broad convenience construct affecting people's behavior and decision-making process $[18,20]$. Moreover, geographic convenience affects other convenience types and is regarded as the prerequisite for other convenience dimensions [18]. For example, a hotel located in the city center positively affects the perceived time and effort convenience, compared to a hotel located in the peripheral area of the city. The same applies to the sharing economy, since convenience is a motivator for growing participation in the sharing economy [23-25]. In P2P accommodation, Airbnb has been increased significantly, and its listings seem to be distributed more sparsely than hotels in cities [14]. Airbnb still tends to be located in the central area of the city for geographic convenience, which leads to the spatial disparity of Airbnb resulting in challenges for city management, affecting rental fees. It is of great value to investigate Airbnb location patterns through the lens of geographic convenience, which is represented as proximity to the city center in this study.

\subsection{Airbnb Studies}

Recent academic studies on Airbnb have addressed a variety of issues such as Airbnb's advantages and challenges [25,26], legal issues [27,28], trust and reputation [29,30], impact on tourism [31,32], price, and other influential factors [33,34]. Several studies explored the spatial patterns of Airbnb in cities. Quattrone et al. [35] explored the geographic and demographic factors affecting Airbnb growth and penetration in London and provided several implications for the regulation of Airbnb. Gutiérrez, García-Palomares, Romanillos, and Salas-Olmedo [14] compared the spatial patterns of Airbnb with hotels and tourist attractions in Barcelona, finding that the distribution of Airbnb has a clear center-periphery pattern, and that Airbnb are closer to the city's main tourist attractions than hotels. Quattrone, Proserpio, Quercia, Capra, and Musolesi [35] identified the social-economic status of areas that benefited from Airbnb business opportunities and provided suggestions for regulating the overwhelimg growth of Airbnb. To summarize, the studies on Airbnb have explored various issues, but so far, none of these studies have examined Airbnb penetration in cities through the lens of geographic convenience and residential clustering, nor have they explored the driving mechanisms of Airbnb spatial patterns using spatial statistics.

\section{Data and Methodology}

\section{Study Area and Data}

Three cities were chosen as our study areas: New York City (NYC), Los Angeles (LA), and Chicago (Chicago). NYC, LA, and Chicago are the top three most populous cities in the USA, with populations of over 8.5 million (NYC), over 3.9 million (LA) and over 2.7 million (Chicago), respectively [36]. These cities are metropolitan areas with a significant impact on commerce, entertainment, politics, tourism, and sports, thus attracting millions of travelers for business, leisure, or a combination. Correspondingly, accommodation demands in these cities are high, which makes them preferred places to start Airbnb. Airbnb in these cities is growing dramatically, which entails huge challenges in terms of managing and monitoring it. Thus, reaching a better understanding of Airbnb in these cities is valuable to sustaining the benefits of travelers' Airbnb experiences.

The Airbnb data for these three cities were obtained from Inside Airbnb (http://insideairbnb. com/get-the-data.html), which provides Airbnb data for multiple cities. The Airbnb data contain a 
variety of information such as locations, prices, reviews, ratings, and room types (shared/private/entire apartment or home) of Airbnb listings. The data used in this study were extracted in July 2017 by Inside Airbnb. Hence, as of July 2017, the number of Airbnb listings in NYC, LA, and Chicago were 41,244 (47,941 bedrooms), 23,132 (31,329 bedrooms), and 5334 ( 8480 bedrooms), respectively. Because different types of bedrooms that Airbnb provides are not equal, we used the total bedrooms offered by Airbnb rather than the number of Airbnb listings to measure Airbnb supply. The spatial distributions of Airbnb supply in terms of bedrooms provided by Airbnb for the three cities are presented in Figure 1 . Airbnb supply predominates in the central areas that attract a considerable number of tourists. Airbnb supply in NYC is concentrated in the Manhattan borough and part of the Brooklyn borough nearby. As for Airbnb supply in LA, it dominates in the West Hollywood and coastal areas. Airbnb supply in Chicago is located intensively along the coastal line of Chicago.
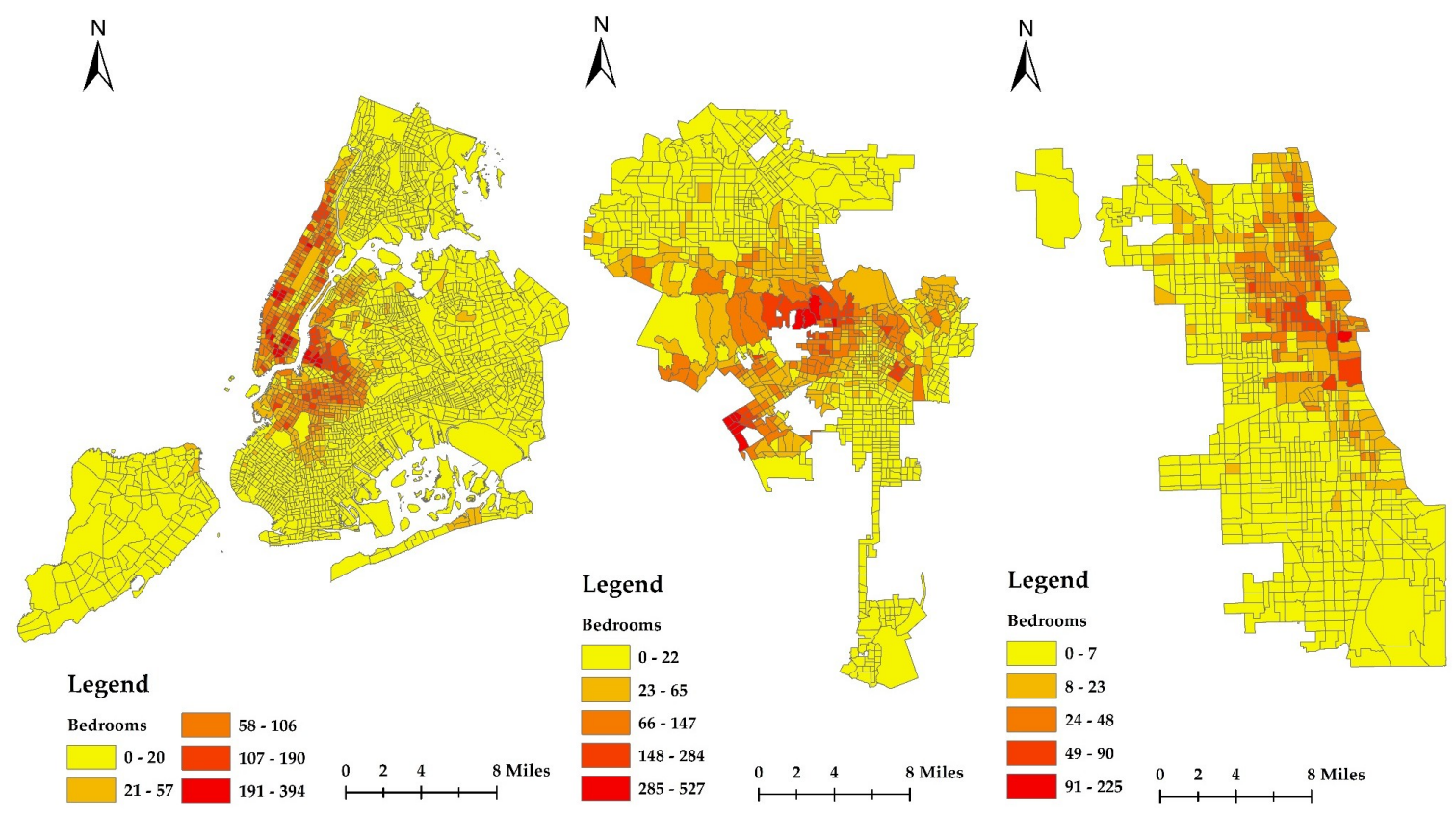

Figure 1. The spatial distribution of Airbnb supply at census tract level in three cities.

In this study, we used the census tract as the geographic unit of analysis. To explore the determinants of Airbnb supply spatial patterns in cities, the socioeconomic data at the census tract level, including employment, population, income, education, and housing units were collected from the American Community Survey (ACS), where detailed information about demographics, social factors, economics, and housing is stored [37]. These socioeconomic variables are commonly recognized as important indictors affecting the spatial patterns of accommodation services. Meanwhile, the geographical convenience variables, the distance to city center, and the number of points of interest (POI) are gathered at the census tract level. The distance to city center was calculated using GIS tools, showing the distance from centroid of each census tract to city center. The POI data was obtained from GEOFABRIK (http://www.geofabrik.de/), where OpenStreetMap data were collected [38]. The POI is a specific point or location (e.g., landmark, park, hospital) that may attract locals and nonlocals' interests, which to some extent can be used to estimate the attractiveness of places. Table 1 lists the information about the dependent variable (Airbnb supply) and explanatory variables. 
Table 1. Description of variables used in spatial regression model.

\begin{tabular}{cc}
\hline Variable & Description \\
\hline $\begin{array}{c}\text { AirbnbSupply } \\
\text { Population }\end{array}$ & Total Number of bedrooms provided by Airbnb \\
Young & Total Number of people \\
Black & The percentage of people aged between 25-44 years \\
The percentage of black people \\
Employment & The ratio of the number of employees over the total population \\
Income & The percentage of bachelor's degree or higher \\
TousingUnit & The median household income (Dollar) \\
Rent & Total number of housing units \\
C-Distance & The median gross rent of occupied units (Dollar) \\
POI & The Euclidean distance to City Center (KM) \\
\hline
\end{tabular}

\section{Methodology}

\subsection{Ordinary Least Square (OLS)}

The OLS regression model is a straightforward and widely-used method to explore the relationships between a dependent variable and a set of explanatory variables. The model can be expressed as:

$$
y=X \beta+\varepsilon,
$$

where $y$ is the dependent variable, $X$ is a set of explanatory variables, $\beta$ is the matrix of estimated coefficients, and $\varepsilon$ is a vector of error terms. The error $\varepsilon$ is assumed to be independently and identically distributed.

\subsection{Spatial Regression Models}

The OLS model may not suitable for spatial data, since there often exists a spatial dependence or spatial autocorrelation in spatial data. Thus, spatial regression models are recommended to be applied when spatial autocorrelation is found in spatial data. In this study, two commonly used models, spatial lag model (SLM) and spatial error model (SEM), were applied to explore the spatial relationships between the dependent variable and explanatory variables. SLM assumes there exists a spatial dependence between observations in the neighboring area, thus attributing spatial dependence to the dependent variable. A spatially lagged dependent variable is included in SLM. The model can be expressed as:

$$
y=\rho W y+X \beta+\varepsilon,
$$

where $y$ is the dependent variable, $X$ is a set of explanatory variables, $\beta$ is the estimated coefficients, $\varepsilon$ is a vector of error terms, $W$ is the spatial weight matrix, and $\rho$ is the spatial autoregression coefficient. There exist spatial dependences among the dependent variables if $\rho$ is statistically significant.

SEM assumes there exists spatial dependence among residuals, therefore attributing spatial dependence to the error by including a spatial error term. SEM is written as follows:

$$
\begin{gathered}
y=X \beta+\varepsilon, \\
\varepsilon=\lambda W \varepsilon+u,
\end{gathered}
$$

where $\lambda$ is the autoregressive coefficient, and $u$ is a vector of independent identically distributed errors. Other notations are the same as before. There exists a spatial dependence in residuals if $\lambda$ is statistically significant. 


\section{Case study}

\subsection{New York City}

The estimated results of three models for NYC are presented in Table 2. The goodness-of-fit statistics, including the Akaike info criterion (AIC) and log-likelihood, are commonly used to evaluate model performance. As shown, the AIC presents a much smaller indicator for spatial regression models (AIC $=18,888.1$ and 18,907.20) than the outcomes of the OLS model (AIC $=20,159.00)$. The spatial error coefficient $(0.7061)$ and spatial lag coefficient $(0.8140)$ are both significant and positive, which strongly demonstrates the existence of spatial dependence. The OLS model has a $56 \%$ explanatory power, while the SLM and SEM has a high explanatory power of $79 \%$ and $80 \%$, respectively, suggesting that spatial regression models perform better than the OLS model when spatial autocorrelation exists. In addition, Lagrange multiplier (LM) tests were undertaken and four LM statistics (LMlag, LMerr, RLMlag, and RLMerr) were obtained, which were used to determine which model is more suitable, SLM or SEM. The model with a significantly larger statistics value is more suitable $[39,40]$. The LM tests results suggest that the SLM model is suitable for NYC.

The estimated SLM results for NYC showed that Young People, Black People, Employment, Education, Housing Unit, and POI have significant and positive effects on Airbnb supply, while Population and Income negatively affect Airbnb supply. Specifically, Airbnb supply is concentrated in those parts of NYC that have a higher proportion of young and black people, a higher employment rate, a lower income, and a more significant education level. It is plausible that Airbnb can make more money while hosting well-educated and employed people who are much responsive towards new technologies. The number of housing units is positively associated with Airbnb supply, while residential population negatively affects Airbnb supply. It is plausible that a large residential population consumes a significant number of housing units, thus leaving few spare housing units for Airbnb. Airbnb supply is strongly related to the nearby attractions (POI), because accessibility of tourist attractions is preferred by guests.

Table 2. Summary of estimation results of three models for New York City.

\begin{tabular}{ccccccc}
\hline & \multicolumn{2}{c}{ OLS } & \multicolumn{2}{c}{ SLM } & \multicolumn{2}{c}{ SEM } \\
\hline & Coefficient & p-Value & Coefficient & p-value & Coefficient & p-Value \\
\hline CONSTANT & -31.5970 & 0.0000 & -32.9712 & 0.0000 & -18.9345 & 0.0000 \\
Population & -0.0029 & 0.0001 & -0.0016 & 0.0027 & -0.0031 & 0.0000 \\
Young & 1.6385 & 0.0000 & 0.5669 & 0.0000 & 0.5507 & 0.0000 \\
Black & 0.1829 & 0.0000 & 0.0575 & 0.0002 & -0.0235 & 0.5512 \\
Employment & 0.2693 & 0.0008 & 0.3776 & 0.0000 & 0.2376 & 0.0001 \\
Education & 0.7038 & 0.0000 & 0.1869 & 0.0000 & 0.2317 & 0.0000 \\
Income & -0.0008 & 0.0000 & -0.0005 & 0.0000 & -0.0003 & 0.0000 \\
HousingUnit & 0.0163 & 0.0000 & 0.0096 & 0.0000 & 0.0155 & 0.0000 \\
Rent & -0.0018 & 0.3537 & 0.0011 & 0.4042 & 0.0036 & 0.0084 \\
C-Distance & -0.8939 & 0.0000 & 0.1527 & 0.0984 & -0.0974 & 0.4684 \\
POI & 0.6633 & 0.0000 & 0.3303 & 0.0000 & 0.4340 & 0.0000 \\
Spatial lag $(\rho)$ & & 0.7061 & 0.0000 & & 0.8140 & 0.0000 \\
Spatial error $(\lambda)$ & & & & 1212.5003 & 0.0000 \\
LMlag/LMerr & & & 1291.0382 & 0.0000 & 0.000 \\
RLMlag/RLMerr & & & 174.7576 & 0.0000 & 96.2196 & 0.0000 \\
R squared & 0.56 & & 0.79 & & 0.80 & \\
Log-likelihood & $-10,068.50$ & & -9432.04 & & -9442.61 & \\
AIC & 20,159 & & $18,888.1$ & & $18,907.20$ & \\
\hline
\end{tabular}

\subsection{City of Los Angeles}

The results of three models for LA are presented in Table 3. The spatial error coefficient (0.7031) and spatial lag coefficient (0.7717) are both significant and positive, suggesting the existence of spatial 
dependence. The OLS model has a $43 \%$ explanatory power, while the SLM and SEM have higher explanatory powers of $73 \%$ and $74 \%$, respectively, indicating spatial regression models fit much better than the OLS model does. In addition, the LM tests results suggest that the SEM model is a more fitting model for LA.

The estimated SEM results for LA showed that Income, Housing Unit, and POI have significant and positive effects on Airbnb supply, while Population and C-Distance negatively affect Airbnb supply. Specifically, Airbnb supply in LA is more likely to predominate in those parts of LA that have higher incomes, which is inconsistent with NYC. This may suggest that people's participation in Airbnb in LA is no longer for making a little extra money. Further, Airbnb supply in LA is more likely to be located close to the city center, resulting in heavier traffic volume of tourists in the central area of the city. Similar to NYC, the number of housing units and number of POI are positively associated with Airbnb supply in LA, and residential population negatively affects the Airbnb supply.

Table 3. Summary of estimation results of three models for Los Angeles.

\begin{tabular}{ccccccc}
\hline & \multicolumn{2}{c}{ OLS } & \multicolumn{2}{c}{ SLM } & \multicolumn{2}{c}{ SEM } \\
\hline & Coefficient & p-Value & Coefficient & p-Value & Coefficient & p-Value \\
\hline CONSTANT & -19.0010 & 0.0622 & -22.8584 & 0.0011 & 10.7356 & 0.2406 \\
Population & -0.0089 & 0.0000 & -0.0021 & 0.0861 & -0.0030 & 0.0177 \\
Young & 0.9335 & 0.0001 & 0.1455 & 0.3535 & -0.0188 & 0.9107 \\
Black & -0.2991 & 0.0102 & -0.0789 & 0.3226 & -0.0211 & 0.8856 \\
Employment & -0.1360 & 0.4968 & 0.0580 & 0.6727 & -0.2375 & 0.0822 \\
Education & 0.2536 & 0.0541 & -0.1343 & 0.1422 & 0.1742 & 0.1348 \\
Income & 0.0004 & 0.0000 & 0.0002 & 0.0000 & 0.0003 & 0.0000 \\
HousingUnit & 0.0323 & 0.0000 & 0.0154 & 0.0000 & 0.0197 & 0.0000 \\
Rent & 0.0023 & 0.5550 & 0.0038 & 0.1654 & 0.0041 & 0.1218 \\
C-Distance & -1.0835 & 0.0000 & -0.4124 & 0.0000 & -1.0920 & 0.0007 \\
POI & 0.7632 & 0.0000 & 0.5274 & 0.0000 & 0.6557 & 0.0000 \\
Spatial lag $(\rho)$ & & 0.7031 & 0.0000 & & 0.7717 & 0.0000 \\
Spatial error $(\lambda)$ & & & & 728.1436 & 0.0000 \\
LMlag/LMerr & & & 728.1299 & 0.0000 & 0.0000 \\
RLMlag/RLMerr & & & 43.2162 & 0.0000 & 43.2298 & 0.0000 \\
R squared & 0.43 & & 0.73 & & 0.74 & \\
Log-likelihood & -5199.44 & & -4891.45 & & -4885.49 & \\
AIC & $10,420.9$ & & 9806.9 & & 9792.97 & \\
\hline
\end{tabular}

\subsection{City of Chicago}

Table 4 illustrates the analytical results of the three models for Chicago. The spatial error coefficient (0.3636) and spatial lag coefficient (0.5020) are both significant and positive, showing the existence of spatial dependence. The OLS model has a $57 \%$ explanatory power, while the SLM and SEM have higher explanatory powers of $62 \%$ and $64 \%$, respectively, indicating that the spatial regression models fit much better than the OLS model. In addition, the LM test results show that the RLMlag statistic is not significant, indicating that the SEM model is the more appropriate model for Chicago.

The estimated SEM results for Chicago showed that Young People, Employment, Housing Unit, and POI have significant and positive effects on Airbnb supply, while C-Distance negatively affects Airbnb supply. Specifically, Airbnb supply predominates in those parts of Chicago that have a higher employment rate and a higher proportion of young people, which is consistent with NYC. The Airbnb supply is more likely to be located around the city center area, which is consistent with LA. Similar to NYC and LA, Airbnb supply in Chicago is positively related to the number of housing units and those of nearby attractions (POI). 
Table 4. Summary of estimation results of three models for City of Chicago.

\begin{tabular}{ccccccc}
\hline & \multicolumn{2}{c}{ OLS } & \multicolumn{2}{c}{ SLM } & \multicolumn{2}{c}{ SEM } \\
\hline & Coefficient & p-Value & Coefficient & p-Value & Coefficient & p-Value \\
\hline CONSTANT & -13.7834 & 0.0001 & -13.8853 & 0.0000 & -4.7902 & 0.2202 \\
Population & 0.0000 & 0.9493 & 0.0001 & 0.8401 & -0.0006 & 0.3126 \\
Young & 0.3969 & 0.0000 & 0.2405 & 0.0009 & 0.1656 & 0.0331 \\
Black & 0.0457 & 0.0035 & 0.0433 & 0.0031 & 0.0099 & 0.6181 \\
Employment & 0.3028 & 0.0000 & 0.2594 & 0.0000 & 0.2014 & 0.0009 \\
Education & 0.1036 & 0.0021 & 0.0310 & 0.3315 & 0.0542 & 0.1872 \\
Income & -0.0002 & 0.0012 & -0.0001 & 0.0125 & -0.0001 & 0.1540 \\
HousingUnit & 0.0032 & 0.0108 & 0.0034 & 0.0038 & 0.0066 & 0.0000 \\
Rent & 0.0004 & 0.8568 & 0.0003 & 0.8947 & 0.0023 & 0.2308 \\
C-Distance & -0.6554 & 0.0000 & -0.4117 & 0.0000 & -0.8908 & 0.0000 \\
POI & 0.3370 & 0.0000 & 0.2732 & 0.0000 & 0.2945 & 0.0000 \\
Spatial lag $(\rho)$ & & 0.3636 & 0.0000 & & 0.5020 & 0.0000 \\
Spatial error $(\lambda)$ & & & & & & \\
LMlag/LMerr & & & 65.4796 & 0.0000 & 74.7679 & 0.0000 \\
RLMlag/RLMerr & & & 1.4463 & 0.2291 & 10.7347 & 0.0011 \\
R squared & 0.57 & 0.62 & & 0.64 & \\
Log-likelihood & -3089.21 & & -3055.25 & & -3042.65 &
\end{tabular}

\subsection{Comparisons across All Three Cities}

Table 5 presents the comparison of determinants of Airbnb spatial patterns across three cities. First, the number of housing units and the number of POI are two common factors that strongly and positively affect Airbnb location patterns in all three cities. This is to be expected, since accessibility to nearby attractions is of great value for travelers to choose a place to stay overnight. Second, the residential population has a significant and negative effect on Airbnb supply in two of three cities (NYC and LA). The distance to the city center has a significant and negative effect on Airbnb supply in LA and Chicago, but not in NYC. Third, the employment rate is positively associated with Airbnb supply in NYC and Chicago but has no significant effect on Airbnb supply in LA. Fourth, the median gross income has a mixed effect on Airbnb supply, demonstrating a negative effect on Airbnb supply in NYC, a positive effect on Airbnb supply in LA, and no effect on Airbnb supply in Chicago. Fifth, the proportion of black people and education enrollment rate has a positive effect on Airbnb supply only in NYC. Sixth, the median rent is not associated with the Airbnb supply across the three studied cities.

Table 5. The comparison of model results of three cities.

\begin{tabular}{cccc}
\hline Variables & New York City & Los Angeles & Chicago \\
\hline Population & - & - & \\
Young & + & & + \\
Black & + & & + \\
Employment & + & & \\
Education & + & + & + \\
Income & - & + & \\
HousingUnit & + & - & - \\
Rent & & + & + \\
C-Distance & & + & + \\
POI & + & & \\
\hline
\end{tabular}

Note: - indicates a negative effect, + indicates a positive effect. 


\section{Conclusions and Future Work}

Under the lens of residential clustering and geographic convenience, this paper examined the Airbnb supply in three cities: NYC, LA, and Chicago. We explored the spatial patterns of Airbnb supply in cities and investigated its influencing factors at the census tract level through utilizing spatial regression models. The spatial regression models performed better than the OLS model did for all three cities, which indicates spatial autocorrelations on Airbnb supply exist. The main conclusion and policy implications of this study concluded that (1) the spatial distribution of Airbnb supply in all three cities has a clear center-peripheral pattern, indicating that Airbnb allocations predominate in the central area of the city; (2) the housing units and POI has an influential impact on Airbnb supply for all three cities; (3) the proportion of young people and employment has a positive effect on Airbnb supply in NYC and Chicago, but not in LA, while the distance to the city center negatively affects the Airbnb supply in LA and Chicago, but not in NYC; (4) income level has a mixed effect on Airbnb supply in all three cities, while the proportion of black people and education level has a positive effect on Airbnb supply only in NYC; and (5) rent is not associated with Airbnb supply for all three cities, which indicates that the Airbnb explosion may not contribute to increases in rent. This result is inconsistent with the findings of Dudás, Vida, Kovalcsik, and Boros [13] because of the outcomes of the geographic unit analysis.

Nevertheless, several limitations are noted to provide potential directions for future research. First, the geographic analysis unit is census tract in this study. Future research may consider using a different geographical scale that can provide valuable insights integrated with Airbnb supply spatial patterns. Additionally, while regression analysis has a certain explanatory power, the driving mechanism behind the Airbnb supply spatial patterns is complex, and the results are contradictory across cases due to various reasons. It is recommended to revisit analyses conducted in this study using other approaches with sufficient theoretical supports to gain a more comprehensive understanding.

Author Contributions: Z.Z. provided literature reviews and quantitative analyses. R.J.C.C. guided the project with direction and ideas, added value to literature reviews, methods, and recommendations. R.J.C.C. also edited the whole manuscript.

Funding: This research received no external funding.

Acknowledgments: We appreciate the journal reviewers' feedback.

Conflicts of Interest: The authors declare no conflict of interest.

\section{References}

1. Rachel, H.; Andrew, M.; Pierre-Dimitri, G.-C. 5 Billion Trips. Available online: https://www.uber.com/ newsroom/5billion-2/ (accessed on 7 May 2018).

2. Airbnb. Fast Facts. Available online: https://press.atairbnb.com/fast-facts/ (accessed on 7 May 2018).

3. Antonacci, G.; Fronzetti Colladon, A.; Stefanini, A.; Gloor, P. It is rotating leaders who build the swarm: Social network determinants of growth for healthcare virtual communities of practice. J. Knowl. Manag. 2017, 21, 1218-1239. [CrossRef]

4. Chenoweth, J. Is tourism with a low impact on climate possible? Worldw. Hosp. Tour. Themes 2009, 1, $274-287$. [CrossRef]

5. Palgan, Y.V.; Zvolska, L.; Mont, O. Sustainability framings of accommodation sharing. Environ. Innov. Soc. Trans. 2017, 23, 70-83. [CrossRef]

6. Fellmann, J.D.; Getis, A.; Getis, J.; Malinowski, J.C. Human Geography: Landscapes of Human Activities; Brown \& Benchmark Publishers: Madison, WI, USA, 1997.

7. Li, H.; Wang, Q.; Shi, W.; Deng, Z.; Wang, H. Residential clustering and spatial access to public services in shanghai. Habitat Int. 2015, 46, 119-129. [CrossRef]

8. Poulsen, M.; Johnston, R.; Forrest, J. The intensity of ethnic residential clustering: Exploring scale effects using local indicators of spatial association. Environ. Plan. A 2010, 42, 874-894. [CrossRef]

9. Iceland, J.; Weinberg, D.H. Racial and Ethnic Residential Segregation in the United States 1980-2000; Bureau of Census: Suitland, MD, USA, 2002. 
10. Johnston, R.; Poulsen, M.; Forrest, J. Ethnic residential patterns in urban england and wales, 2001-2011: A system-wide analysis. Tijdschrift voor Economische en Sociale Geografie 2016, 107, 1-15. [CrossRef]

11. Lichter, D.T.; Parisi, D.; Taquino, M.C. The geography of exclusion: Race, segregation, and concentrated poverty. Soc. Probl. 2012, 59, 364-388.

12. Thebault-Spieker, J.; Terveen, L.; Hecht, B. Toward a geographic understanding of the sharing economy: Systemic biases in uberx and taskrabbit. ACM Trans. Comput. Hum. Interact. 2017, 24, 21. [CrossRef]

13. Dudás, G.; Vida, G.; Kovalcsik, T.; Boros, L. A socio-economic analysis of airbnb in new york city. Reg. Stat. 2017, 7, 135-151. [CrossRef]

14. Gutiérrez, J.; García-Palomares, J.C.; Romanillos, G.; Salas-Olmedo, M.H. The eruption of airbnb in tourist cities: Comparing spatial patterns of hotels and peer-to-peer accommodation in barcelona. Tour. Manag. 2017, 62, 278-291. [CrossRef]

15. Berry, L.L.; Seiders, K.; Grewal, D. Understanding service convenience. J. Mark. 2002, 66, 1-17. [CrossRef]

16. Seiders, K.; Voss, G.B.; Godfrey, A.L.; Grewal, D. Servcon: Development and validation of a multidimensional service convenience scale. J. Acad. Mark. Sci. 2007, 35, 144-156. [CrossRef]

17. Farquhar, J.D.; Rowley, J. Convenience: A services perspective. Mark. Theory 2009, 9, 425-438. [CrossRef]

18. Jones, M.A.; Mothersbaugh, D.L.; Beatty, S.E. The effects of locational convenience on customer repurchase intentions across service types. J. Serv. Mark. 2003, 17, 701-712. [CrossRef]

19. Srivastava, M.; Kaul, D. Social interaction, convenience and customer satisfaction: The mediating effect of customer experience. J. Retail. Consum. Serv. 2014, 21, 1028-1037. [CrossRef]

20. Wong, I.A.; Zhao, W.M. Exploring the effect of geographic convenience on repeat visitation and tourist spending: The moderating role of novelty seeking. Curr. Issues Tour. 2014, 19, 824-844. [CrossRef]

21. Jin, B.; Kim, J.O. A typology of korean discount shoppers: Shopping motives, store attributes, and outcomes. Int. J. Serv. Ind. Manag. 2003, 14, 396-419. [CrossRef]

22. Anselmsson, J. Sources of customer satisfaction with shopping malls: A comparative study of different customer segments. Int. Rev. Retail Distrib. Consum. Res. 2006, 16, 115-138. [CrossRef]

23. Puschmann, T.; Alt, R. Sharing economy. Bus. Inf. Syst. Eng. 2016, 58, 93-99. [CrossRef]

24. Belk, R. You are what you can access: Sharing and collaborative consumption online. J. Bus. Res. 2014, 67, 1595-1600. [CrossRef]

25. Guttentag, D. Airbnb: Disruptive innovation and the rise of an informal tourism accommodation sector. Curr. Issues Tour. 2015, 18, 1192-1217. [CrossRef]

26. Lampinen, A.; Cheshire, C. Hosting via Airbnb: Motivations and Financial Assurances in monetized network hospitality. In Proceedings of the 2016 CHI Conference on Human Factors in Computing Systems, San Jose, CA, USA, 7-12 May 2016; ACM: New York, NY, USA, 2016; pp. 1669-1680.

27. Lee, D. How airbnb short-term rentals exacerbate los angeles's affordable housing crisis: Analysis and policy recommendations. Harv. Law Policy Rev. 2016, 10, 229.

28. Edelman, B.G.; Geradin, D. Efficiencies and regulatory shortcuts: How should we regulate companies like airbnb and uber. Stanf. Technol. Law Rev. 2015, 19, 293. [CrossRef]

29. Ert, E.; Fleischer, A.; Magen, N. Trust and reputation in the sharing economy: The role of personal photos in airbnb. Tour. Manag. 2016, 55, 62-73. [CrossRef]

30. Liang, L.J.; Choi, H.C.; Joppe, M. Understanding repurchase intention of airbnb consumers: Perceived authenticity, electronic word-of-mouth, and price sensitivity. J. Travel Tour. Mark. 2017, 1-17. [CrossRef]

31. Choi, K.H.; Jung, J.H.; Ryu, S.Y.; Do Kim, S.; Yoon, S.M. The relationship between airbnb and the hotel revenue: In the case of Korea. Indian J. Sci. Technol. 2015, 8. [CrossRef]

32. Zervas, G.; Proserpio, D.; Byers, J.W. The rise of the sharing economy: Estimating the impact of airbnb on the hotel industry. J. Mark. Res. 2017, 54, 687-705. [CrossRef]

33. Wang, D.; Nicolau, J.L. Price determinants of sharing economy based accommodation rental: A study of listings from 33 cities on airbnb.Com. Int. J. Hosp. Manag. 2017, 62, 120-131. [CrossRef]

34. Zhang, Z.; Chen, R.J.; Han, L.D.; Yang, L. Key factors affecting the price of airbnb listings: A geographically weighted approach. Sustainability 2017, 9, 1635. [CrossRef]

35. Quattrone, G.; Proserpio, D.; Quercia, D.; Capra, L.; Musolesi, M. Who benefits from the sharing economy of airbnb? In Proceedings of the 25th International Conference on World Wide Web, Montréal, QC, Canada, 11-15 April 2016; International World Wide Web Conferences Steering Committee: Geneva, Switzerland, 2016; pp. 1385-1394. 
36. U.S. Census Bureau. American Factfinder-Results. Available online: https://factfinder.census.gov/faces/ tableservices/jsf/pages/productview.xhtml?src=bkmk (accessed on 9 March 2018).

37. U.S. Census Bureau. Amercian Fact Finder. Available online: https:/factfinder.census.gov/faces/nav/jsf/ pages/index.xhtml (accessed on 12 March 2018).

38. Geofabrik. Openstreetmap Data Extracts. Available online: http://download.geofabrik.de/ (accessed on 12 March 2018).

39. Fischer, M.M.; Getis, A. Handbook of Applied Spatial Analysis: Software Tools, Methods and Applications; Springer Science \& Business Media: Berlin/Heidelberg, Germany, 2009.

40. Fischer, M.M.; Wang, J. Spatial Data Analysis: Models, Methods and Techniques; Springer Science \& Business Media: Berlin/Heidelberg, Germany, 2011.

(C) 2019 by the authors. Licensee MDPI, Basel, Switzerland. This article is an open access article distributed under the terms and conditions of the Creative Commons Attribution (CC BY) license (http://creativecommons.org/licenses/by/4.0/). 